\title{
PREHISTORIA KSIAŻKI POLSKIEJ WE FRANCJI (OD XIV W. DO POWSTANIA LISTOPADOWEGO)
}

Przyjęcie przez Polskę chrześcijaństwa wprowadziło ją do europejskiej rodziny narodów, pośrednio wiażąc także z Francją. Pienwsze nasze poselstwo przybyło do tego kraju w końcu XI wieku. W tymże stuleciu zawitali pierwsi polscy studenci, pielgrzymi i kupcy. Jednak Francuzi długo nie interesowali się Polską. Pierwszy jej francuski opis dał dopiero Wilhelm de Machaut, który w 1363 r. przebywał w Krakowie z okazji ślubu wnuczki Kazimierza Wielkiego, Elżbiety, z cesarzem Karolem IV Luksemburgiem. Do głębszego, choć często subiektywnego poznania Polski oraz ukształtowania opinii o Polakach przyczyniły się dopiero dość liczne publikacje, dla których impulsem stała się w 1573 r. elekcja Henryka Walezjusza na króla Polski. Znalazły się wśród nich przekłady prac polskich, m.in. Jana Herburta "Histoire des Roys et des Princes de Pologne" (1573).

Wcześniej, bo w 1531 r. wyszła w Paryżu pierwsza bodaj ksiażka polskiego autora - francuski przekład łacińskiego poematu Jana Dantyszka „Victoria Sereniss. Poloniae Regis contra voyevodam Muldaviae [...]". Natomiast w 1560 r. w paryskiej tłoczni drukarza-humanisty Roberta Estienne'a (Stephanusa) ukazał się pierwszy we Francji, a zarazem w ogóle na Zachodzie, tekst polskojęzyczny. Było to „Epitaphium in mortem Herrici [!] Gallorum regis [...]”, które napisał po hebrajsku w 1559 r. na wieść o tragicznej śmierci króla Henryka II zamieszkały w Paryżu flamandzki poeta i humanista Karol Utenhove. Epitafium to ukazało się jednocześnie w 12 językach, w tym po polsku, co było na pewno następstwem bliskich kontaktów autora z Polakami, m.in. Janem Baptystą Tęczyńskim i Janem Kochanowskim 1 .

Na początku XVII w. osiadł w Paryżu i nie opuścił go aż do śmierci (około 1630 r.), wywodzący się ze Lwowa Jan Ziarnko, który zyskał duże uznanie Francuzów jako sztycharz i ilustrator wielu ksiażek i wydawnictw okolicznościowych. Swoje dzieta podpisywał zazwyczaj z francuska Jean Le Grain, ale często z dopetnieniem Polonus lub Leopoliensis ${ }^{2}$.

Jest oczywiste, że powodzeniu dzieł Ziarnki nie mogła dorównać pierwsza prawdopodobnie w całości polskojęzyczna książka wydana we Francji - „Arsenał miłosierdzia Panny Przenaświętszey Mariey przeciw surowey sprawiedliwości Boskiey na ziemi [...]" Kazimierza Jana Woysznarowicza. Dla nas jest ona jednak nader ważna. Wydrukował ją w 1668 Ludovici Sevestre w swojej oficynie mieszczącej się w Paryżu przy ul. des Amandiers. Złożono ją czcionkami francuskimi, ale z uwzględnieniem polskich znaków diakrytycznych uzyskanych poprzez przeróbki i różne kombinacje znaków graficznych. Tę ponad 130-stronicową książkę 
zdobią, co warto jeszcze podkreślić, bordiury drzeworytowe, listwy z ornamentu typograficznego, inicjały figuralne i drzeworytowe finaliki ${ }^{3}$.

Renesans zainteresowania Polską przyniósł ślub francuskiej księżniczki Ludwiki Marii Gonzagi, która w 1645 r. wyszła za mąż za Władysława IV, a w 1649 r. za jego brata i następcę na tronie polskim Jana II Kazimierza. Jej podróż do Polski została obszernie zrelacjonowana przez Jeana de Labourera („Relations du voyage de la Royaume de Pologne [...]”. Paris 1647), a „Gazette de France" zaczęła odtąd zwracać uwagę na wiadomości z Rzeczypospolitej. Okres panowania Jana III Sobjeskiego (1674-1696), chociaż także ożenionego z Francuzką, nie był korzystny dla rozwoju stosunków polsko-francuskich. Natomiast wydarzenia zwiazane z bezkrólewiem po jego śmierci, a wśród nich wybór na tron polski przez część elektorów Francuza ks. Louisa Françoisa de Contego (1697), wywołały we Francji kolejny wzrost zainteresowania sprawami polskimi. Ich owocem byla m.in. poczytna „Histoire de Pologne et du Grand Duché de Lithuanie” J.G.Jolli'ego (Amsterdam wyd. 1.1698, wyd. 2.1699).

Przez pierwsze dziesiątki lat XVIII stulecia, podobnie jak dawniej, źródłem większości poloników francuskich były kolejne polskie elekcje i królewskie mariaże polsko-francuskie, a także trzydziestoletnie panowanie Polaka w Lotaryngii. Tym razem chodzłło o Marię Leszczyńska, która w 1725 r. poślubiła króla Ludwika XV oraz jej ojca, Stanisława Leszczyńskiego, dwukrotnie zdetronizowanego króla Polski, który w 1736 r. otrzymał w dożywotnie władanie księstwa Lotaryngii i Baru. Jego dwór w Luneville, rychło nazwany Wersalem Lotaryngii, stał się ośrodkiem nauki i kultury promieniującym na całą Francję, a nawet na całą Europę. Sławę zyskały założone przez Leszczyńskiego w 1750 r., a istniejące po dziś dzień, Société royale des sciences et belles-lettres de Nancy (później Académie de Stanislas) oraz Bibliothèque publique de la ville de Nancy. Na szeroko otwartym dworze lunewilskim gościło wielu Polaków, a wśród nich Józef Andrzej Załuski, który - jako wielki jałmużnik Lotaryngii - rezydował tu w latach 1737-1742 (z kilkumiesięczną przerwą na przełomie 1738 i 1739 r.). Tutaj zaciągnąwszy długi, zgromadził on księgozbiór, który zajłł cały przeznaczony mu apartament, a w 1743 r. - zapakowany w 83 skrzynie i przewieziony do Warszawy - wszedł w skład powstałej parę lat później Biblioteki Załuskich. ${ }^{4}$ Plany naukowe Akademii uwzględniały studia o Polsce (de Solignac), a Biblioteka Publiczna w Nancy stała się m.in. skarbnicą poloników ${ }^{5}$. Wśród licznych ówczesnych publikacji bezpośrednio bądź pośrednio wiażących się ze Stanisławem Leszczyńskim i jego córką oraz ich otoczeniem, znalazły się kolejne druki polskojęzyczne - „Głos wolny wolność ubezpieczający" Leszczyńskiego (Nancy 1743$)^{6}$ oraz w jego przekładach „Rozmowy duszy z Panem Bogiem wybrane ze słów św. Augustyna [...]” Denisa-Xaviera Clémenta (Nancy 1745) i „Historia Starego i Nowego Testamentu” Nicolasa Fontaine'a (Nancy 1761) ${ }^{7}$.

Za panowania Stanisława Augusta Poniatowskiego stosunki polsko-francuskie rozwijały się bujnie. Wielu Polaków ciągnęło nad Sekwanę. Studiowali tu m.in. Adam Naruszewicz, Stanisław Staszic i Tadeusz Kościuszko. W 1769 r. zjawili się w Paryżu emisariusze barzan, a na przełomie 1773 i 1774 r. - po klęsce konfederacji 
barskiej - napłynęła do Francji pierwsza fala polskiej emigracji politycznej. Później miały przyjść następne, niestety częste i liczne.

Wysłannicy przywódców kolejnych zrywów niepodległościowych oraz wszystkie fale wychodźstwa politycznego starały się zainteresować Francję i Francuzów swoją ojczyzną i pozyskać ich dla sprawy polskiej. Ich inspiracja dała asumpt do powstania wielu prac o Polsce. Początek tej działalności dali emisariusze barzan. To im zawdzięczać należy m.in. narodziny takich dziet, jak „O rąidzie i prawach Polski” („De Gouvernement et des lois de Pologne”) Gabriela de Mably czy „Uwagi o rądzie polskim” („Consideration sur le gouvernement de Pologne”) Jana Jakuba Rousseau (1772 + liczne wydania późniejsze).

W arsenale środków propagandowych emigracji poczesne miejsce znalazły też własne publikacje obliczone $z$ jednej strony na poruszenie obcych rządów i opinii publicznej, a z drugiej - na mniej lub bardziej jawny kolportaż w kraju. We Francji w ostatniej ćwierci XVIII w. zainicjowano całą serię francuskojęzycznych broszur propagandowo-politycznych. Książki w języku polskim, również o wymowie politycznej, zaczęto wydawać nieco później. Na pierwszy ogień poszły bodaj dwa wydania „Uwag politycznych nad ninieyszymi okolicznościami, mogące służyć za ciąg dalszy Historyi Rewolucyi Francuzkiey" pastora kalwińskiego i członka władz w początkowym okresie francuskiej rewolucji Jeana Paula Rabaut'a (Nancy 1792, Strasburg 1794). Pierwszą z tych edycji wytłoczono w Warszawie u Michała Grölla, a drugą w oficynie Jeana George'a Treuttela w Strasburgu staraniem Kuźnicy Kołłątajowskiej, z myślą rozprzestrzeniania idei rewolucyjnych ${ }^{8}$. Rok 1800 przyniósł dwie książki wydane w Paryżu - „Postanowienie konsulów Rzeczypospolitej Francuzkiej względem urządzenia gospodarstwa [... ]" oraz rzekomo tłoczoną w Prykopiu nad Donem, a naprawdę nad Sekwaną, słynną broszurę „Czy Polacy mogą wybić się na niepodległość" ułożoną z inspiracji Tadeusza Kościuszki przez Józefa Pawlikowskiego ${ }^{10}$.

We wrześniu 1812 r. paryski drukarz i księgarz de Chaignieau âiné (starszy) wytłoczył dwujęzyczną (polsko-francuska) książkę André René de Chazeta „Moskale w Polszcze. Opis historyczny od koka [!] 1762 do naszych dni", którą można było kupować u niego (ul. de Monnaie 11), u czterech dalszych księgarzy paryskich (Delanuay, Colnet, Martinet, Le Normant) oraz we wszystkich większych księgarniach warszawskich. Dwa lata później nadsekwańską tłocznię L.G. Machaud'a (ul. Des Bons-Enfants 34) opuścita „Mowa przy obchodzie pogrzebowym $\mathrm{J}$ : 0 : Xiazecia Jozefa Poniatowskiego" Franciszka Dzierżykraja Morawskiego, a w 1815 r. w tymże mieście ujrzała światło dzienne przemowa „Polak do współrodaków swoich z okazyi przywróconego Królestwa Polskiego" Piotra Bogorowskiego. Przynajmniej dwie pienwsze $z$ tych książek wydrukowano czcionkami nie mającymi polskich znaków diakrytycznych, w ogóle pomijając te znaki, bądź - jak w przypadku "Moskali w Polszcze" - wymowę niektórych polskich dźwięków starając się oddać na „sposób francuski” (ą=on, np. pamiontka, formuionc; $\mathrm{e}=e n, n p$. rence uciente). Był to krok wstecz, gdyż wszystkie omówione wcześniej XVII- i XVIII-wieczne publikacje polskie we Francji miały polskie znaki diakrytyczne - często wcale udatnie skomponowane $z$ różnych akcentów i czcionek francuskich, a niekiedy odbite ze specjalnie odlanych pojedynczych czcionek (litery ą i ę). 
Tylko dwa zestawienia statystyczne obejmujące dłuższy okres czasu z ogółu wydawanych poloników (w pojęciu estreicherowskim) wyróżniają polonica zagraniczne $^{11}$. Obydwa są jednak nader ułomne, uwzględniają tylko lata 1794-1893 (1913), a nadto znacznie - aż parokrotnie - na niekorzyść poloników zagranicznych, zaniżają proporcje pomiędzy nimi a pozostałymi polonikami. Można więc oprzeć się wyłącznie na własnych (wprawdzie orientacyjnych, ale trafnie oddających skalę zjawiska) obliczeniach wynikających z wyrywkowej analizy chronologicznej serii „Bibliografii polskiej" $K$. Estreichera ${ }^{12}$. Wynika z niej, że od I rozbioru Polski w 1772 r. do ustanowienia Królestwa Kongresowego w 1815 r. za granicą wydano 1892 polonica, co stanowi 9,5\% ogółu uwzględnionych przez Estreichera poloników. Na ziemach leżących poza granicami przedrozbiorowej Polski (1772) zdecydowanie najwięcej poloników wydano w tym czasie w Niemczech - 1041 (tj. $5,2 \%$ ogólu poloników i 55\% poloników zagranicznych). Francja znalazła się pod tym wzgiędem na drugim. miejscu - 251 tytułów $(1,26 \%$ ogółu poloników i 13,3\% poloników zagranicznych) nieznacznie wyprzedzając Rosję (195) i Austrię (196) i już wyraźnie - Anglię (89), Włochy (69), Holandię (30) i Szwajcarię (14). W samym Paryżu spośród owych 251 poloników wyszło aż 225, 8 ukazało się w Strasburgu, a 7 w Lyonie. W pozostałych miastach wydano tylko pojedyncze (1-2) polonica. W latach dwudziestych XIX stulecia (próbka $z$ lat 1820 i 1825) udział poloników zagranicznych w ogólnej liczbie poloników utrzymywał się na zbliżonym poziomie $(11,3 \%)$. Nadal najwięcej wydawano ich w Niemczech $-58,3 \%$. Francja umocniła się na drugim miejscu (27 publikacji w latach 1820 i 1825) - 22,5\% - wyraźnie dystansując już wszystkie pozostałe kraje. Zdecydowany prymat jako francuskie centrum poloników utrzymał Paryż (24 z 27 druków).

Różnorodne, dość żywe na przestrzeni wieków, kontakty polsko-francuskie mogłyby wskazywać, że Francuzom nie jest obca Polska, jej kultura i burzliwe, a na przełomie XVIII i XIX stulecia tragiczne dzieje. Znalazłoby się niemało przesłanek podbudowujących taką hipotezę. Francjaw rozlicznych okolicznościach gościła wielu Polaków, niekiedy przyjmując nawet duże ich grupy - np. gości lunewilskiego dworu Stanisława Leszczyńskiego, emigrujących z kraju konfederatów barskich oraz uczestników epopei napoleońskiej. Taż Francja była „ojczyzną" szeregu poloników wydawniczych, zajmując pod tym względem - naturalnie poza samą Polską - drugie miejsce; przed ościennymi dla Polski państwami, a zarazem jej zaborcami - Rosją i Austrią. We Francji znajdowala się, założona przez St. Leszczyńskiego i zasobna w polonica z jego okresu, Biblioteka Publiczna w Nancy. Można by zatem uważać, że istnieją dobre, poniekąd naturalne warunki do ukształtowania się we Francji ważnego polskiego ośrodka, mającego w swoim programie działania m.in. promocję kultury i w ogóle sprawy polskiej na arenie międzynarodowej, ochronę dóbr kultury narodowej, których los na ziemiach polskich stawał się coraz mniej pewny oraz zaspokajanie potrzeb duchowych rodaków w kraju i na obczyźnie.

Aż tak dobrze jednak nie było. W latach dwudziestych XIX w. Polacy budzili żywą sympatię w społeczeństwie francuskim, ale wiedza o nich, o ich rozdartych pomiędzy zaborców ziemiach, o Królestwie Polskim rządzonym przez cara w duchu rzekomo liberalnym, była niedostateczna, często fragmentaryczna i oparta na 
obiegowych stereotypach. Wspomnienia o ludziach z północy wiernie i do końca walczących u boku Napoleona, wdzięczność wobec Polski, która nie tak dawno jeszcze udzielała schronienia Francuzom uchodzącym z kraju z przyczyn politycznych, czy też coraz powszechniejsza ciekawość, jaką budziły odległe, egzotyczne terytoria sprawiły, że zainteresowanie Polską nie malało, wręcz rosło. Na tej fali spod piór Francuzów pojawiały się wciąz nowe artykuły i książki traktujące o Polsce. Motyw polski zagościł w popularnych melodramatach i innych utworach literackich. Nierzadko publikacje te były jednak nafaszerowane wiadomościami zniekształconymi lub fałszywymi, pochodzącymi z drugiej, a nawet trzeciej ręki. Działo się tak m.in. dlatego, że nie było we Francji żadnej instytucji, stowarzyszenia czy choćby nieformalnej grupy, mającej przede wszystkim na celu promowanie, wydawanie i gromadzenie rzeczy polskich bądź Polski dotyczących. Chociaż od ukazania się we Francji pierwszego tekstu w języku polskim minęło ponad 250 lat, w dalszym ciągu żadna tamtejsza drukarnia nie dysponowała czcionkami z polskimi znakami diakrytycznymi.

Te widoczne zaniedbania postanowił naprawić wychowanek Uniwersytetu Wileńskiego, były filareta i sekretarz ks. Michała Kleofasa Ogińskiego, Leonard Chodźko ${ }^{13}$, który po śmierci swego pracodawcy, w 1826 r. osiadł na stałe w Paryżu. Tutaj, przy pomocy kolegi z lat studenckich, byłego redaktora „Dziennika Warszawskiego" Michała Podczaszyńskiego ${ }^{14}$, nakreślił ambitny i szeroki plan propagowania kultury polskiej we Francji. Obejmował on m.in. umieszczanie artykułów w prasie, czasopismach, encyklopediach i innych wydawnictwach francuskich oraz ogłaszanie dzieł polskich, zarówno w języku francuskim, jak i polskim. Dla realizacji swych zamierzeń obaj ci młodzi i energiczni ludzie pozyskali znaczące poparcie paryskiego drukarza J. Pinarda (ul. d'Anjou-Dauphine 8) oraz parysko-genewskich „przedsiębiorców” (księgarzy, wydawców) J. Barbezata i Delarue (Paryż ul. de Grammont 7, Genewa ul. du Rhône). Więcej, z ich francuskich firm zdołali uczynić przyczółek dla przyszłych instytucji książi polskiej nad Sekwaną.

Publikacjom francuskojęzycznym Leonard Chodźko dał początek wydaniem „Mémoires sur la Pologne et les Polonais [...]” ks. Ogińskiego poprzedzonych własnymi „Observations sur la Pologne et les Polonais” (Paryż 1826-1827) wytłoczonymi przez Crapeleta, a przyjętymi na skład m.in. przez Barbezata i Delarue. Niebawem przygotował własna „Histoire des Légions Polonaises en Italie [...]", która aż w dwóch wydaniach ukazała się w Paryżu w 1829 r. Wydrukował ją J. Pinard, a wydawcami lub komisantami byli znowu Barbezat i Delarue. Rok 1830 przyniósł z kolei wydaną przez J. Barbezata (bez wspólnika) dwutomową „Histoire de Pologne" Józefa Zielińskiego, będącą przeróbką „Historii ksiażąt i królów polskich” Teodora Wagi. O sprawach polskich Chodźko zaczął też pisywać m.in. W „Biographie universelle portative des contemporains" (Paryż 1826-1831), "Le Globe” (1830), "Le Journal des débats (1831), „Le Spectateur Militaire” (1831) i „Nouvelle biographie générale" (Paryż 1857-1866).

Wydawnictwa w języku polskim Chodźko pragnął zainicjować dziełami Adama Mickiewicza. Realizacja tego zamierzenia wymagała jednak wyszukania mecenasa, który sfinansowałby odlanie kompletnego garnituru polskich czcionek. Została nim hr. Klementyna z Sanguszków Ostrowska, która zgodziła się łożyć nie tylko na 
czcionki, ale i całą edycję. Pieniądze rozwiązały wszystko. Druku, a być może także wykonania pierwszego we Francji zestawu polskich czcionek, podjał się J. Pinard. W rezultacie, opracowane przez Chodźkę, wzorowe pod względem szaty graficznej, dwa pienwsze tomy „Poezji” Mickiewicza ukazały się w połowie 1828 r. w nakładzie 1000 egzemplarzy. Na skład główny przyjęli je zaprzyjaźnieni z Chodźką - Barbezat i Delarue ${ }^{15}$. Trzeci tom „Poezji”, wytłoczony w tejże oficynie, wyszedł w 1829 r. Jego wydanie sfinansował J. Barbezat (bez wspólnika), który w specjalnym uwiadomieniu oświadczał, że tom ten drukuje własnym nakładem ,jedynie dla dogodzenia publiczności polskiej". W ten sam sposób, rok później, doszedł do skutku pokaźny tom dzieł zebranych Ignacego Krasickiego, przygotowany tym razem przez M. Podczaszyńskiego ${ }^{16}$.

Leonard Chodźko przez długie jeszcze lata realizował swój program szerzenia za granicą wiedzy o Polsce. W tym momencie szczególnego znaczenia nabiera jednak fakt, że jego działalność propagandowo-wydawniczą, a także kolekcjonerską - choć prowadzoną w dużej mierze jednoosobowo - można potraktować jako zaczątek, czy może raczej namiastkę pierwszej instytucji książki polskiej we Francji. Nie mniej ważne jest to, że dzięki jego zapałowi i wysiłkom już pierwsza fala Wielkiej Emigracji zastała w nadsekwańskiej stolicy przyjazną przybyszom znad Wisły, dobrze wyposażoną w polskie czcionki drukarnię A. Pinarda (dawniej J. Pinarda), przeniesioną tymczasem na Quai Voltaire 15.

\section{Przypisy}

Tekst polski pt. „Ostatnia prozba Henrika Krolia francuskiego do Pana Boga przed samym skonaniem" mieści się na karcie B1r, Przy braku czcionek z poiskimi znakami diakryłycznymi, właściwości polskiej ortografii starano się oddać tak, aby była choć względnie zgodna z francuską wymową. Por.: Stanisław Kot, Pierwszy wiersz polski tłoczony w Paryżu. "Silva Rerum” 1928, T. 4, s. 1-5 oraz odbitka: Kraków 1928; K. Estreicher, Bibliografia polska. T. 32. Kraków 1938, s. 103-104.

${ }^{2}$ S. Sawicka, J. Ziarnko, Peintre-graveur polonais et son activité à Paris. "La France et la Pologne dans leur Relations Artistiques" 1938, vol. 1, fasc. 2/3, s. 101-257; Taż, Ziarnko Jan. W:] Słownik pracowników książki polskiej, Warszawa 1972, s. 1019-1020.

${ }^{3}$ Adres drukarni ustalono na podstawie: G. Lepreux, Gallia typographica [...]. T. 1, Paris 1911, s. 9.

${ }^{4}$ K. Muszyńska, Załuski Józef Andrzej, [W:] Slownik pracowników książki polskiej, s. 1005-1006;

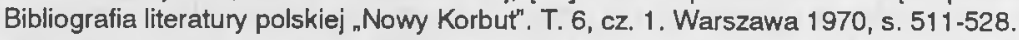

${ }^{5}$ Arnold Kirszbraun, Z działalności Stanislawa Leszczyńskiego w Lotaryngii. (Akademia i Biblioteka Publiczna w Nancy). [W:] Księga pamiątkowa ku uczczeniu dwudziestopięcioletniej działalności naukowej Prof. Marcelego Handelsmana, Warszawa 1929, s. 139-145; E. Chwalewik, Zbiory polskie. [Wyd. 2]. T. 2. Warszawa 1927, s. 2. W zbiorach Biblioteki znajduje się m.in. wielka księga in folio $z$ rękopisami wydanych i niewydanych prac Stanisława Leszczyńskiego.

${ }^{6}$ [Stanislaus Leszczyríski], Głos wolny wolność ubezpieczający, [B. m. dr.] 1733 [wł.: Nancy, 1743], $19 \times 16 \mathrm{~cm}, \mathrm{~s} .150$.

7 Augustinus Aurelius s., Entretiens de l'ame avec Dieu [...] par [...] l'abbé [Denis-Xavier] Clement [...]. Rozmowy duszy z Panem Bogiem wybrane ze słów świętego Augustyna [...]. Thum. S. Leszczyński]. [Nancy, b. dr.] 1745, $19 \times 12 \mathrm{~cm}$, s. 403. Druk dwujęzyczny: francuski i polski; [Nicolas Fontaine], Historya Starego y Nowego Testamentu [...] z francuskiego wierszem polskim przethumaczona [przez S. Leszczyńskiego]. Nancy, w Drukarni Piotra Antoine lego Krolewskiey MCl y Miasta Typografa, 1761, 39 x $24 \mathrm{~cm}$, s. 743. Piękny druk, bordiury.

${ }^{8}$ [Jean Paul] Rabaut, Uwagi polityczne nad niniejszymi okolicznościami mogące służyć za ciąg dalszy historyi rewolucyi francuzkiey [...]. Nancy, znayduie sie w Straźburgu u Jerzego Treuttel, 1792, 12 × 8 
cm, s. 45. Druk - jak ustalił na podstawie analizy typograficznej Józef Szczepaniec - w warszawskiej oficynie Michała Grölla. Toż: [...]. Z przydatkiem anekdotów [...]. Strazburg, Druk J.G.Treuttla, 1794, 15 $\times 9 \mathrm{~cm}$, s. 48 .

Kamuflażem było podanie Metz w adresie wydawniczym pierwodruku (1793) znanej pracy H. Kołątaja i l. Potockiego "O ustanowieniu i upadku Konstytucji polskiej 3 Maja 1791". W rzeczywistości publikacja ta ukazala się w Lipsku lub Krakowie.

${ }^{9}$ Postanowienie Konsulów Rzeczypospolitej Francuzkiej względem urządzenia gospodarki i kalkulacji korpusów [...]. Podpisal Generał Prezyd. Wielohorski. [B. m. dr. i r.] [Paryż 1800], s. 34. (Opis za „Bibliografią polską" K. Estreichera, t. 3, s. 501).

${ }^{10}$ [Józef Pawlikowski], Czy Polacy wybić się mogą na niepodleglość? W Prykopiu nad Donem [wł.: Paryż, Baudoin] $1800,8^{\circ}$, s. 60 .

${ }^{11}$ A. Potocki, Polska literatura współczesna. Cz. 2. Warszawa 1912. Tablice zamieszczone na końcu ksiażki, obejmujące lata 1794-1893, opracowane zapewne na podstawie tablicy statystycznej przygotowanej na wystawe krajowa we Lwowie w 1894 r.; E. Romer, I. Weinfeld, Rocznik Polski. Tablice statystyczne, Kraków 1917. Obejmuje m.in.: statystykę wydawnictw za lata 1794-1913. Toż pt. „Annuaire statistique polonais". Tamże 1917. Por. M. Czarnowska, llościowy rozwój polskiego ruchu wydawniczego 1501-1965, Warszawa 1967, s. 25-31.

${ }^{12}$ A. Potocki do historycznych ziem polskich wlącza szereg miast nie należących do Rzeczypospolitej przed I rozbiorem (np. Kjów, Wroclaw, Nysa). Ale gdyby nawet skorygować te błędy, to i tak podawane przez niego liczby poloników byłyby znacznie zaniżone. llustruje to poniższa tabelka:

\begin{tabular}{|c|c|c|c|c|c|c|}
\hline \multirow{2}{*}{ Lata } & \multicolumn{2}{|c|}{ Polonica wg Potockiego } & \multicolumn{2}{|c|}{$\begin{array}{c}\text { Polonica wg skorygowa- } \\
\text { nego Potockiego }\end{array}$} & \multicolumn{2}{|c|}{$\begin{array}{c}\text { Polonica wg obliczeń } \\
\text { A.Ka podstawie } \\
\text { "Bibliografii polskiej" } \\
\text { K. Estreichera) }\end{array}$} \\
\cline { 2 - 7 } & ogółem & $\begin{array}{c}\text { w tym } \\
\text { Francja }\end{array}$ & ogółem & $\begin{array}{c}\text { w tym } \\
\text { Francja }\end{array}$ & ogółem & $\begin{array}{c}\text { w tym } \\
\text { Francja }\end{array}$ \\
\hline $1794-1798$ & 88 & 7 & 111 & 7 & 237 & 27 \\
$1809-1813$ & 46 & 3 & 129 & 3 & 262 & 58 \\
1832 & 96 & 52 & 104 & 52 & 319 & 146 \\
\hline
\end{tabular}

E. Romer il. Weinfeld podają te same dane liczbowe co A. Potocki.

13 Leonard Chodźko (1800-1871) do 1833 r. należał do najczynniejszych dzialaczy emigracji. Później poświęcił się prawie wyłącznie działalności naukowej i literackiej. W 1854 r. zostal podbibliotekarzem w Bibliotece św. Genowefy, następnie bibliotekarzem francuskiego Ministerstwa Oświaty i wreszcie urzędnikiem w Bibliotece Sorbony. Byl członkiem zarządu Towarzystwa Czytelni Polskiej, działającego w Paryżu w latach 1869-1872. Z pasją gromadził publikacje emigrantów, książki, rękopisy, mapy, sztychy $\mathrm{i}$ inne dokumenty dotyczące Polski, które po jego śmierci stały się fundamentem Biblioteki Rapperswilskiej. Zob. Bibliografia literatury polskiej "Nowy Korbut". T. 7. Warszawa 1968, s. 212-215; W. Swięcicka, Chodźko Leonard. W:] Stownik pracowników książki polskiej, s. 119; W. Borkowska, Chodźko Leonard. [W:] Polski stownik biograficzny. T. 3. Kraków 1937, s. 386-388; M. Straszewska, Życie literackie Wielkiej Emigracji we Francji. 1831-1840, Warszawa 1970, s. 12-15.

14 Michal Podczaszyński (1797-1835) był dzialaczem emigracyjnym, m.in. w latach 1832-1833 redagował i wydawał „Pamiętnik Emigracyji”. Zob. Bibliografia literatury polskiej "Nowy Korbut". T. 9. Warszawa 1972, s. 35-37; S. Kalembka, Chodźko Leonard. [W:] Polski slownik biograficzny. T. 27. Wroctaw 1988, s. 77-79; M. Straszewska, Życie literackie [...], s. 16-18.

15 M. Straszewska, Życie literackie [...], s. 23.

${ }^{16}$ A. Mickiewicz, Poezje. T. 1. Paryż 1828 s. I-VII (przedmowa L. Chodźki); Toż. T. 3. Paryż 1829, zamieszczona przed kartą tytułową ośmiostronicowa reklama podpisana przez J. Barbezata. Zob. też: 
Teofil Syga, Te księgi proste. Dzieje pierwszych polskich wydań ksiażek Mickiewicza, Warszawa 1956, s. 63-72; M. Straszewska, Życie literackie [...], s. 22-23; Ludwik Gocel, Drukarnie polskie na emigracji (1832-1862). "Kwartalnik Prasoznawczy” 1958, nr 1/2, s. 28; Andrzej Feliks Grabski, Z dziejów księgarstwa polskiego w Paryżu. ${ }_{n}$ Roczniki Biblioteczne" R. 4: 1960, z. 1/2, s. 156-158. M.in. M. Straszewska (op.cit. s. 158), L. Gocel (op.cit. s. 28) i A.F.Grabski (op.cit. s. 157) popehnili błąd pisząc, że Pinard przejął czcionki polskie po upadku firmy Barbezata. Jak łatwo stwierdzić, na podstawie autopsji omawianych wydań „Poezji" Mickiewicza i „Dziel” I. Krasickiego, Barbezat i Delarue byli tylko księgarzami-nakladcami nie zajmującymi się drukiem książek polskich. Czyniła to przez cały czas oficyna Pinarda. 